\title{
Plankton variation in Río Cuarto Lake, Costa Rica (2013-2017)
}

\author{
Gerardo Umaña-Villalobos ${ }^{1,2 *}$ \& Lidia Avilés-Vargas ${ }^{1,2}$ \\ 1. CIMAR, Universidad de Costa Rica; gauv301@gmail.com \\ 2. Escuela de Biología, Universidad de Costa Rica; lidiav804@gmail.com \\ * Correspondence
}

Received 20-XI-2018. Corrected 06-VIII-2019. Accepted 03-X-2019.

\begin{abstract}
In tropical lakes, seasonal changes in plankton dynamics are minimal and irregular, since climatic conditions are fairly stable throughout the year, in most cases only long-term studies allow observing patterns in the dynamics of the plankton. Lake Río Cuarto is a maar-type meromic lake located in the plains of Northern Costa Rica, in the past there have been no limnological studies more than a year of sampling, in this work we present data on the composition of phytoplankton and zooplankton over four years, from 2013 to 2017, with the aim of analyzing changes in the plankton community in a longer period, associated with environmental variables. Phytoplankton was studied from subsurface samples, preserved in Lugol's solution and zooplankton from $20 \mathrm{~m}$ vertical hawls of a $64 \mu \mathrm{m}$ mesh net, and preserved with formaline and later transferred to $95 \%$ ethanol. Phytoplankton composition included 54 taxa, most of them were Chlorophyta, followed by Cyanobacteria and Bacillariophyta. The most abundant were: Synechococcus spp., Aphanocapsa sp. Coenochloris fotii, Chlorella sp. and Discostella stelligera. Total phytoplankton decreased from 2013 to 2017, mainly due to a decrease in Cyanobacteria. Zooplankton comprised 14 taxa, 5 cladocerans, 4 copepods, 1 diptera and 4 rotifers. The most abundant were: Keratella americana, Brachionus falcatus, Eubosmina tubicen and Arctodiaptomus dorsalis. There was a substitution of dominant species through time, at first (2013-2014) K. americana and E. tubicen alternated in dominance, and later (2015-2016), A. dorsalis, Diaphanosoma sp. and Ceridaphnia sp. became dominant, with a return of $K$. americana by 2017 . The changes that occurred during the time of the study seem to be related to changes in the conditions of the lake, since its thermocline deepened with time and became more transparent. The abundance, of rotifers and Eubosmina tubicen, decreased associated to a decrease of Cyanobacteria. Those changes were not cyclical on an annual basis, but seemed to occur more on a long-term basis, as has been recognized earlier in the literature about tropical lakes.
\end{abstract}

Key words: phytoplankton, zooplankton, temporal variation, meromictic lake, Costa Rica.

Umaña-Villalobos, G., \& Avilés-Vargas, L. (2019). Plankton variation in Río Cuarto Lake, Costa Rica (2013-2017). Revista de Biología Tropical, 67(6), 1543-1559.

The plankton is a one of the main components of a lake ecosystem. It includes a great variety of forms, from small photosynthetic Cyanobacteria and pico eucariotic microalgae, to large complex organisms such as dinoflagelates and metazoan groups such as Rotifers, Cladocerans and Copepods, among other organisms. All these interact in complex ways with other planktic components or suspended organic matter (Suthers, 2009). These organisms depend on the environmental conditions in the lake, which are influenced by different factors, including seasonal weather variations, and other influencing factors such as long-term climate variations (Arrieiraa et al., 2016; Zehrer, Burns, \& Flöder, 2014). Such variations occur mainly as changes in the composition of the planktic assemblage, either through 
changes in species composition, or through changes in the relative abundance of the dominant groups.

This seasonality has attracted much attention from researchers, mainly at mid and high latitudes, where seasonality is more evident, especially in temperature conditions. In these studies, it has been observed that the seasonality of the plankton follows a fairly predictable path of change along the year, which repeats almost unaltered from year to year (Reynolds, 1984b). This situation has allowed the establishment of models that describe the path of change in species composition of phytoplankton according to lake conditions, such as the one proposed by Reynolds (1984a), or the model of seasonal changes produced by the Plankton Ecology Group in Europe (Sommer, Gliwicz, Lampert, \& Duncan, 1986; Sommer et al., 2012). In tropical lakes seasonal changes in plankton dynamics are minimal and irregular and is mainly related to rainfall, because rains induce modifications in the physical and chemical characteristics of the water (Figueredo \& Giani, 2001), the interpretation of zooplankton dynamics is difficult, mainly by changes in the regularity of seasonal patterns (Twombly, 1983).

In tropical lakes long-term studies are less abundant, especially; most of studies are based on population variation for short periods no greater than two years, and the relationship with physical and chemical factors. Some important studies in tropics about plankton variations are: Lewis (1978a), Lewis (1978b), Twombly (1983), and Imevbore (1967). In the Neotropical region these kinds of studies have been even less common and are mainly focused on reservoirs and floodplains (Twombly \& Lewis, 1987; Simões, Lansac-Tôha, Velho, \& Bonecker, 2012). In Costa Rica there are a few studies focused on zooplankton variations. For example, in Fraijanes Lake there is a study about zooplankton variations for one year (Umaña-Villalobos, Avilés-Vargas, \& Esquivel-Garrote, 2018) and in Barva Lake there is a study about the phytoplankton variations for one year (Umaña-Villalobos, 2010).
Currently studies related to zooplankton variation are focused on the trophic level (PintoCoelho, Pinel-Alloul, Méthot, \& Havens, 2005; Offem, Ezekiel, Ikpi, Ochang, \& Ada, 2011; Claps, Gabellone, \& Benítez, 2011; Rodriguez et al., 2015; Pérez et al., 2013; Figueredo \& Giani, 2001) and climate change (De Senerpont et al., 2012).

Lake Rio Cuarto offers the chance to study changes in plankton species composition with time due to the fact that it has been studied frequently since the late 1970's by different authors (Gocke, Bussing, \& Cortés, 1987; Umaña, 1985; Camacho \& Charpentier-Esquivel, 1985; Ramírez-Ramírez, Tabash-Blanco, \& Charpentier-Esquivel, 1990; Haberyan, Umaña, Collado, \& Horn, 1995), and has been studied again from 2013 to 2017 by our team. In the case of phytoplankton, Camacho and Charpentier-Esquivel (1985) described the changes in the phytoplankton composition along one year, in 1984-1985. They found a total of 14 microalgae species, most of which belonged to the Chlorophyta, and that the most abundant species was Mougeotia genoflexa. The phytoplankton showed higher abundances during the rainy period, when the mixolimnion had a more pronounced stratification (Charpentier et al., 1988). Umaña-Villalobos (1985) also reported the composition of the phytoplankton at this lake in the previous year (1983-1984) and found a total of 16 species of microalgae, but in his case, although Mougeotia was present, the most abundant species were from the Cyanobacteria, mainly three forms of Anabaena sp., which were more abundant at in October-November, 1984. In their sampling in 1991, Haberyan et al. (1995) found that the phytoplankton was dominated by Cyanobacteria, a species of Merismopedia and several green algae. In the case of zooplankton, Ramírez-Ramírez et al. (1990) studied its variation for more than one year in Río Cuarto, and they reported greater diversity of the rotifera with the species: Keratella americana, Polyarthra vulgaris, Pompholyx complanata, Hexarthra intermedia, Euchlanis dilatata and Lecane sp.; Cladocera was represented by 
Diaphanosoma spinulossum and Bosmina longirostris. The highest diversity of organisms was reported during the rainy season. Haberyan et al. (1995) sampled 30 lakes in Costa Rica for phytoplankton and 17 for zooplankton, among them Río Cuarto, during July and August 1991. They only give data on the presence of zooplankton species, which included: Bosmina hagmanni, Ceriodaphnia cornuta, Diaphanosoma cornuta and insect larvae.

For this lake, we hypothesize that the abundance and diversity of organisms change over time in response to environmental conditions. Also, we aim to give a description of the planktic structure in Lake Rio Cuarto at present, during a four-year study, and to offer some hints of possible explanations of changes in planktic composition and the relationships among both components of the planktic assemblage.

\section{MATERIALS AND METHODS}

Study site: Lake Río Cuarto is a meromictic lake located at the northern low plains of Costa Rica $\left(10^{\circ} 35^{\prime} 72^{\prime \prime} \mathrm{N} \& 84^{\circ} 21^{\prime} 89^{\prime \prime} \mathrm{W}\right)$. Its morphometry was described by Gocke et al. (1987). It is located at $380 \mathrm{~m}$ above sea level and has a surface area of 33.2 ha. Its maximum depth is of $66 \mathrm{~m}$ with a mean depth of 45 . It is surrounded by a relatively flat land, mainly used for cattle farming and some agriculture. Forest cover still remains in the steep shoreline that encircles the lake, but the rest of its drainage basin was already deforested by 1950's. According to previous studies the lake has remained between a mesotrophic to eutrophic state during the past 30 years (Umaña-Villalobos \& Farah-Pérez, 2018).

Methods: From January 2013 to November 2017 Lake Río Cuarto was visited several times along each year, for a total of 22 sampling visits; the lake was sampled between 11:00 and 12:00 each time. In 2013, it was visited in May, June, July, August, October and November; in 2014 it was visited in January, February, May, July, August and October; in the year 2015 the samplings were carried out in January, March,
May, July, October and November; in the year 2016 it was visited only in March and April; finally in the year 2017 it was visited in February, May, October and November

During each visit, a single sampling was taken in the center of the lake. At the same point, samples of phytoplankton, zooplankton and physical-chemical parameters were taken by replication. Phytoplankton samples were withdrawn from the subsurface (about $50 \mathrm{~cm}$ depth) and preserved with Lugol's solution. Samples were later analyzed with the Utermöhl technique, sedimenting $50 \mathrm{~mL}$, for identification and enumeration of microalgae. Zooplankton samples were taken by hauling a $64 \mu \mathrm{m}$ mesh-size net; vertically from a depth of $20 \mathrm{~m}$. Samples were preserved with $4 \%$ formalin, and later transferred to ethanol at $70 \%$, prior to identification and enumeration at the laboratory at CIMAR. For the phytoplankton identification the following books were used: Huber-Pestalozzi (1955, 1961, 1968a, 1968b); John, Whitton, and Brook (2005); Komárek (1983); Krammer and Lange-Bertalot (1991); Wehr and Sheath (2003) and West and West (1904, 1905, 1908, 1912, 1923). For zooplankton identification were used: Fernando (2002), Kotov and Stifter (2006) and Shiel (1995).

Physical and chemical parameters were also sampled in each visit. The parameters and the sampling methodology are described in Umaña-Villalobos and Farah-Pérez (2018). For the purposes of this study, of the mentioned parameters we will use Secchi disc depth, thermocline depth and nutrient level (ammonim, nitrite, nitrate and phosphate); since, these parameters could be related to the abundance and diversity of plankton. Thermocline depth was obtained from a depth profile of oxygen and temperature using a probe (Model YSI 6600 V2). Nutrient levels (ammonim, nitrite, nitrate and phosphate) were measured on filtered water samples. Samples were kept in a cooler for transportation to the Marine Chemistry Laboratory at CIMAR, where all nutrients were determined with an autoanalyzer (Model Labchat 8500) based on Parsons, Maita, and Lalli (1984). 
In order to detect whether there is any pattern of variation in the composition of the assemblage of phytoplankton and zooplankton, a Correspondence Analysis (CA) was employed. In the case of phytoplankton data, it was based on the 17 most abundant taxa, and for the zooplankton all species were included. A generalized linear model was employed to test for tendencies of species richness and total abundance of plankton with time. A Canonical Correspondence Analysis (CCA) was performed to examine separately the relationships between phytoplankton and zooplankton and the main physical and chemical parameters defined before, and also between phytoplankton and zooplankton, taking the phytoplankton data as the environmental variables that would explain the zooplankton variation. All analysis were performed with the Vegan (CCA analysis) and FactoMineR (CA) libraries of the $\mathrm{R}$ package (R Core Team, 2013), and PAST software (Hammer, Harper, \& Ryan, 2001). All the tests, for both zooplankton and phytoplankton were carried out with the density of organisms per liter.

\section{RESULTS}

Physico chemical variation: Along the study period the mixing depth of the lake fluctuated, but showed a tendency to become deeper with time, it changed from $15 \mathrm{~m}$ at the beginning, down to $25 \mathrm{~m}$ at the end of the studied period (Fig. 1A). At the same time, Secchi depth increased from $2 \mathrm{~m}$ at the beginning, down to $6 \mathrm{~m}$ by the end of the study (Fig. 1B).
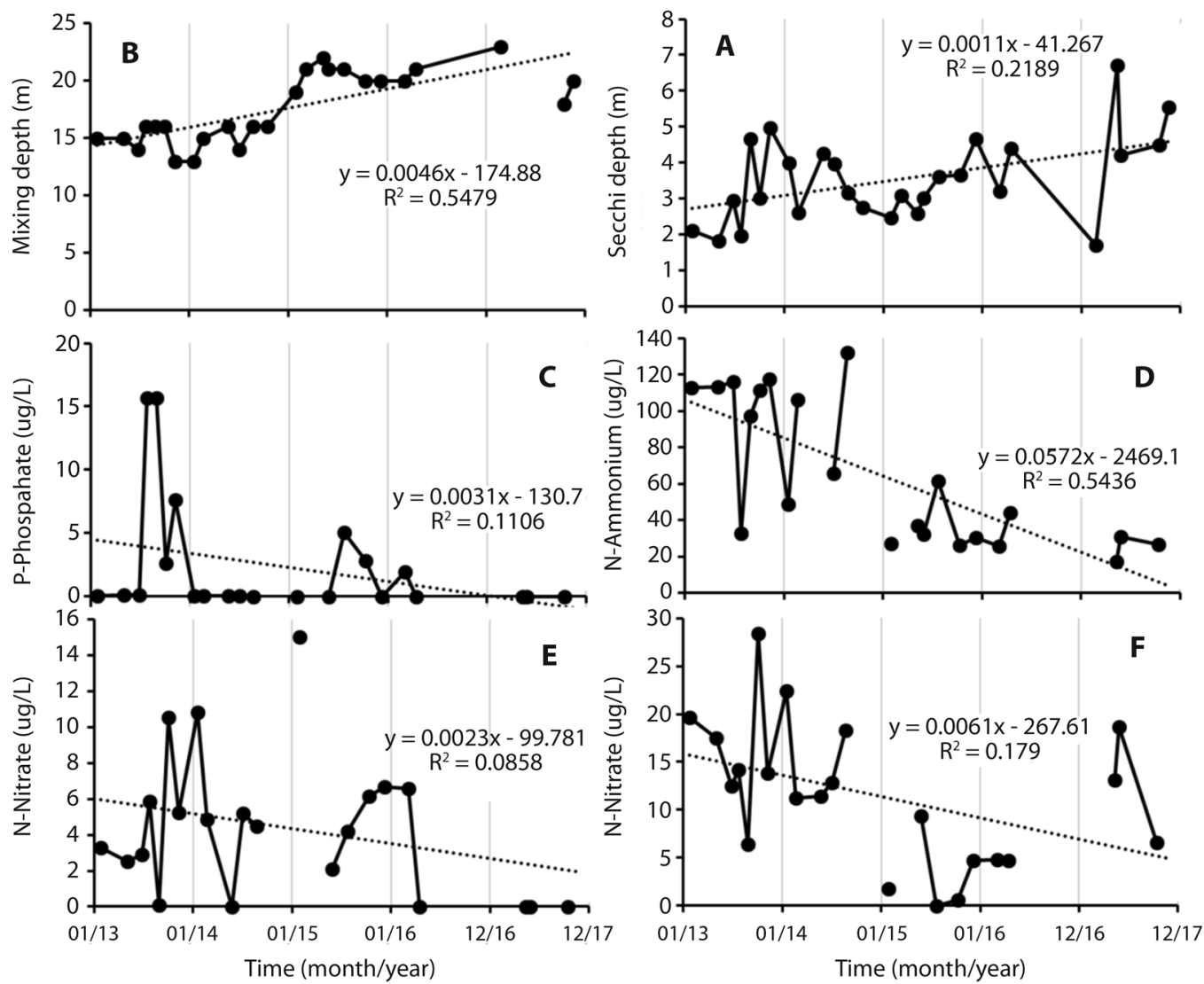

Fig. 1. Temporal variation of several environmental parameters in Lake Río Cuarto for the period 2013-2017. A) Secchi depth (m); B) Mixing depth (m); C) Orthophosphate ( $\mu \mathrm{g} / \mathrm{L})$; D) Ammonium ( $\mu \mathrm{g} / \mathrm{L}) ;$ E) Nitrate $(\mu \mathrm{g} / \mathrm{L}) ; \mathrm{F}) \mathrm{Nitrite}(\mu \mathrm{g} / \mathrm{L})$. Missing points are due to missing data in the data base. Nutrient values are averages over the whole water column. 


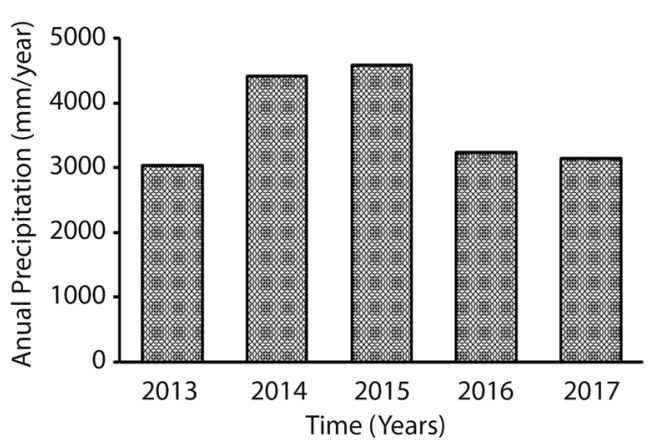

Fig. 2. Annual precipitation (mm/year) at the nearest weather station from Río Cuarto. Data from the Instituto Meteorológico Nacional (IMN). Station: 69709 San Gerardo de Sarapiquí.

In the case of dissolved nutrients, orthophosphate and nitrate were not detectable in most occasions, but both did attain higher values in the period between 2014 and 2015, than later on. Ammonium showed a clear tendency to decrease with time, as did nitrite (Fig. 1C, Fig. 1D, Fig. 1E and Fig. 1F). Weather data were taken from a near station that belongs to the Instituto Meteorológico Nacional (IMN). Annual precipitation is shown in Figure 2, total precipitation in the region around the lake was higher during 2014 and 2015, than the rest.

Phytoplankton: The microalgae composing the phytoplankton of Lake Río Cuarto belong to at least 54 taxa. Most of the taxa belong to Chlorophyta, with 29 taxa, followed by Cyanobacteria and Bacillariophyceae, each with 6 taxa, and Cryptophyta and Dinophyta with five taxa each (Appendix 1). The most abundant taxa were all from Cyanobacteria, including two unidentified morphotypes consisting of loose, lone coccoid cells, presumably of the genus Synechococcus sp. (Cyanobacteria 1, Cyanobacteria 2), and a species of Aphanocapsa sp. Among the green algae, the most abundant species were Coenochloris fotii and Chlorella sp., and the most abundant diatom was Discostella stelligera.

The total abundance of phytoplankton decreased with time (GLM: $\mathrm{G}=37.79, \mathrm{P}=$ $7.85 \times 10^{-10}$ ), as a result of a decreased in the density of Synechococcus sp. (Fig 3A). At the same time, species richness per date fluctuated between a minimum of 11 species in August 2013 and a maximum of 27 in January 2015,

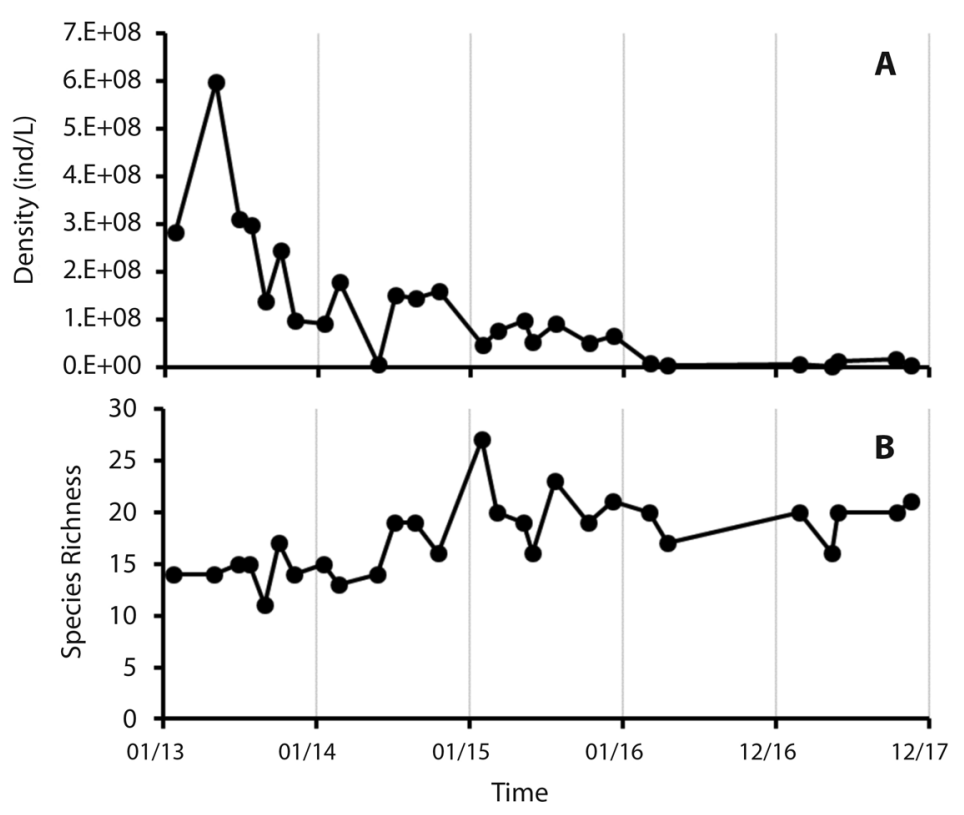

Fig. 3. Temporal variation of phytoplankton's total density (A) and species richness (B) at Lake Río Cuarto 2013-2017. 
and showed a tendency to increase with time along the study period (Fig. 3B) (GLM: $\mathrm{G}=$ $\left.15.13, \mathrm{P}=9.09 \times 10^{-5}\right)$. Another Cyanobacteria, Aphanocapsa sp., showed lower abundance in the period between 2015 and 2016, but showed an increase in 2017. Other species such as $C$. stelligera, O. lacustris and Amphidinium sp. increased with time, but their abundance was more than two orders of magnitude lower than the most abundant Cyanobacteria. On the other hand, some species, like Cystodinium sp. had abundance peaks in the samples from 2015 and 2016 but decreased again by 2017 (Fig. 4).

The Correspondence Analysis (CA) of the phytoplankton variation with the 17 most abundant and frequent species revealed that the changes in these species separated the samples in two groups (Fig. 5); the first from 2013 to 2015 and the second from 2016 and 2017.
The separation of both groups was explained by the changes in Synechococcus sp., together they explained $82.3 \%$ of the total variance in a SIMPER analysis.

The result of the Canonical Correspondence Analysis (CCA) between the most abundant phytoplankton and the physical and chemical data reveal that, both, nutrient concentrations, and physical conditions of the water column, summarized here with Secchi depth and mixing depth explained the variation of the species $(\lambda 1=0.040,50.07 \%$ of the variance; $\lambda 2=0.015,18.33 \%)$. Both morphospecies of Synechococcus sp. were positively related to the nutrient concentrations as they were located at the left side of the figure, but showed a negative relationship with Secchi and mixing depth, O. lacustriss on the contrary was positively related with mixing and Secchi
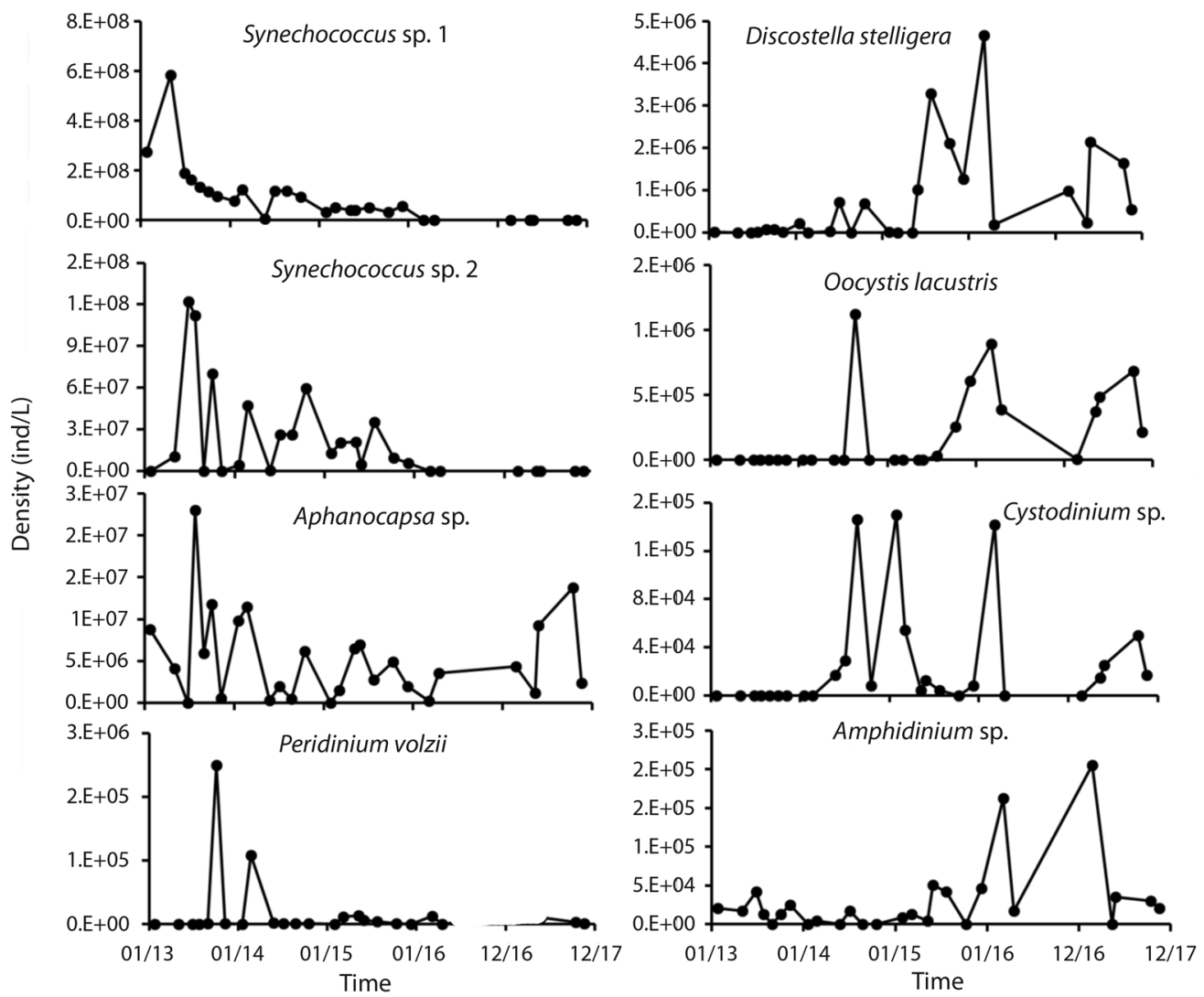

Fig. 4. Temporal variation of the most abundant and frequent species of phytoplankton at Lake Río Cuarto 2013-2017. 
depth, and negatively with nutrient concentrations (Fig. 6).

Zooplankton: It was composed of 14 taxa: five cladocerans, four copepods, one diptera and four rotifers (Appendix 2). These groups were very abundant in 2013 and 2014, with two high peaks mainly due to the abundance of rotifers. In 2015, the abundance of organisms decreased, and remained at low densities in the samplings in 2016 and 2017. From 2015 to
2016 the average number of organisms per date were below 5 ind / L. (Fig. 7A), the decreasing tendency however was not significant $(\mathrm{G}=$ 3.30, $\mathrm{P}=0.06932$ ). Species richness fluctuated between five and ten per date, with no tendency with time $(\mathrm{G}=1.20, \mathrm{P}=027354)$ (Fig. $7 \mathrm{~B})$.

The decrease in abundance is mainly the result of the decline of the most abundant species. The most abundant rotifer was Keratella americana with large peaks in November 2013 and May 2014, and then it presented

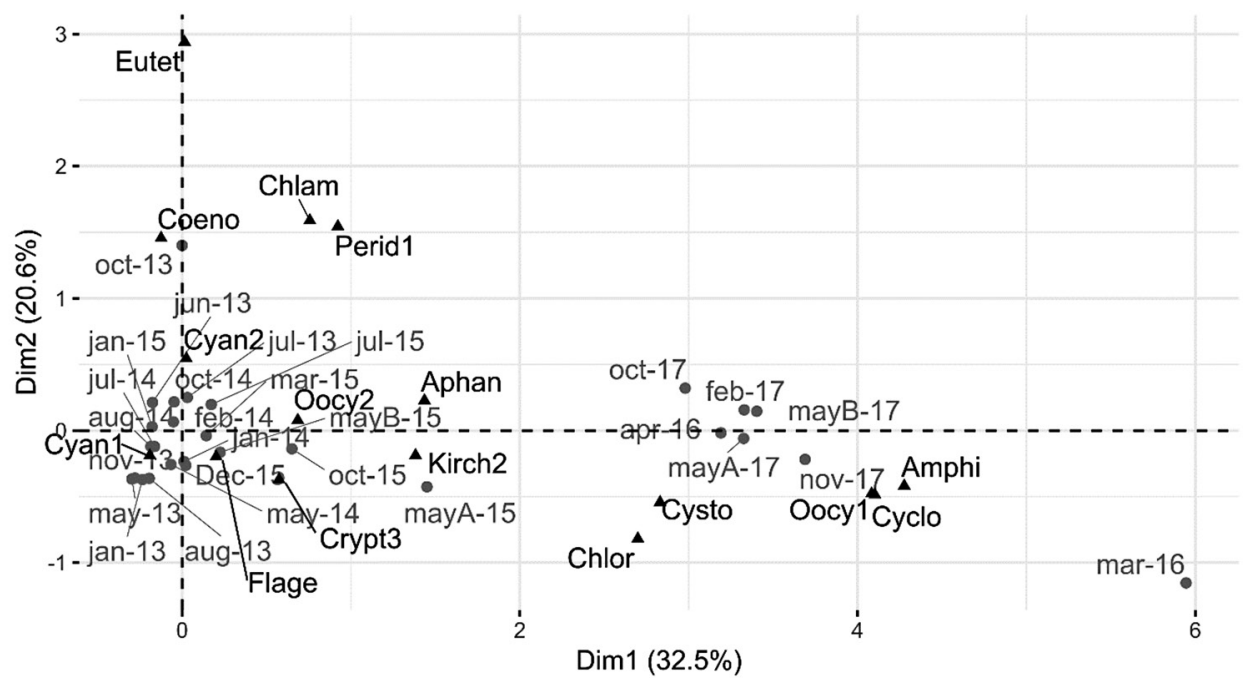

Fig. 5. Result of the CA of the temporal samplings of phytoplankton, based on the most abundant species at Lake Río Cuarto 2013-2017.

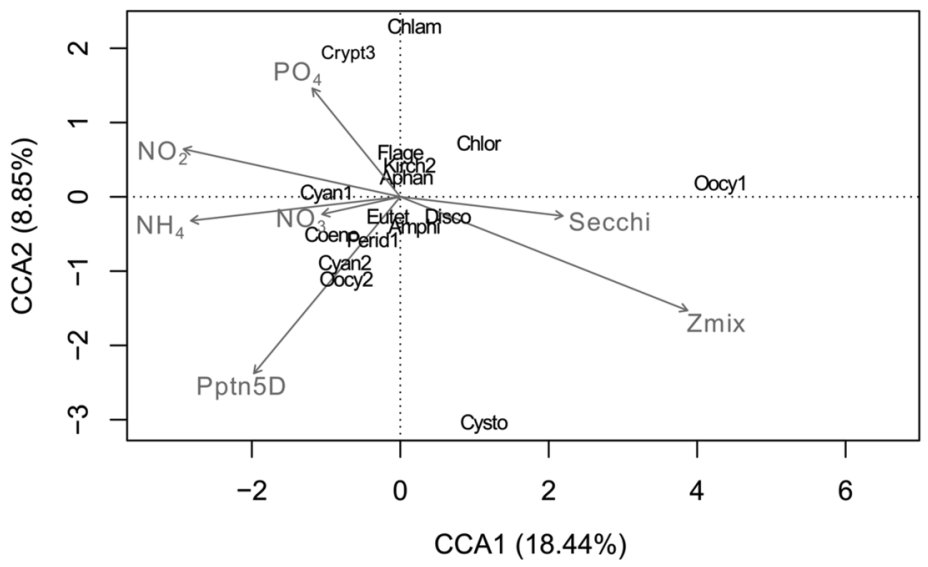

Fig. 6. Result of the CCA of the relationship among environmental parameters and the most abundant species of phytoplankton at Lake Río Cuarto 2013-2017. 

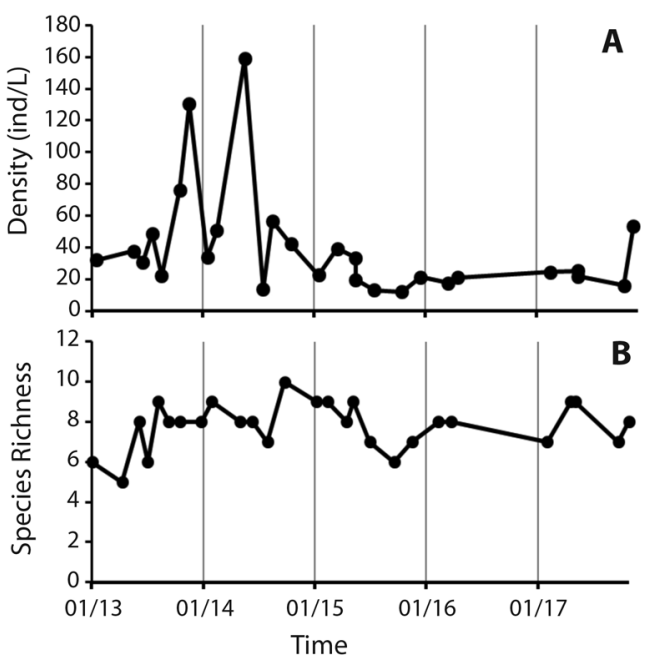

Fig. 7. Temporal variation of zooplankton's total density (A) and species richness (B) at Lake Río Cuarto 2013-2017. small peaks in October 2014 and February 2017. Brachionus falcatus was abundant only until 2013 (Fig. 8). Eubosmina tubicen was little abundant in 2015 and 2016, large peaks are observed in January 2013 and February 2014. Other species with low abundances remained constant or showed an increase in recent years. Diaphanosoma sp. and Ceriodaphnia sp. showed this behavior, these species were abundant from 2014 to 2017, with several peaks in abundance. The most abundant copepod turned out to be Arctodiaptomus dorsalis, this copepod presented constant abundance, with a peak of abundance in August 2014. The naupli larvae remained constant also during the years (Fig. 8).

In the Correspondence Analysis (CA) it is evident a grouping of the species by dates.
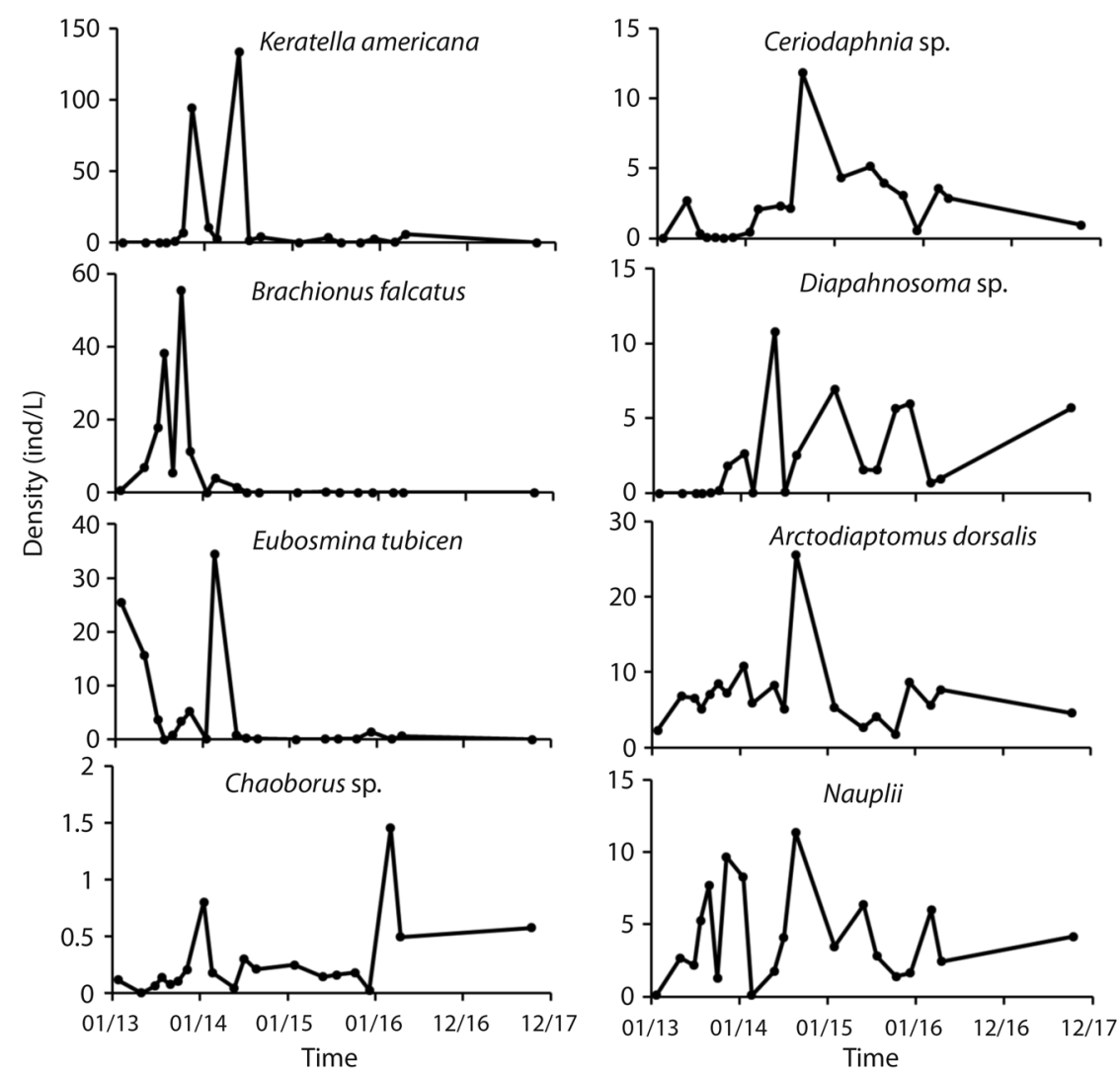

Fig. 8. Temporal variation of the most abundant and frequent species of zooplankton at Lake Río Cuarto 2013-2017. 


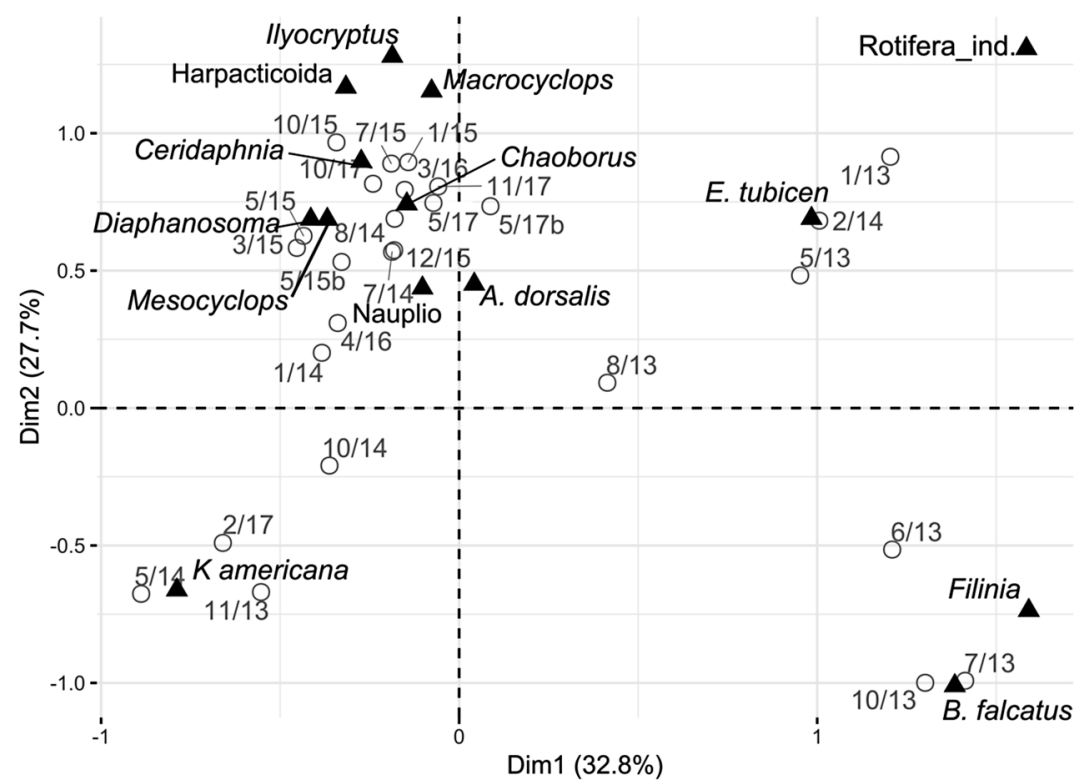

Fig. 9. Result of the CA of the temporal samplings of zooplankton, based on the most abundant species at Lake Río Cuarto 2013-2017.

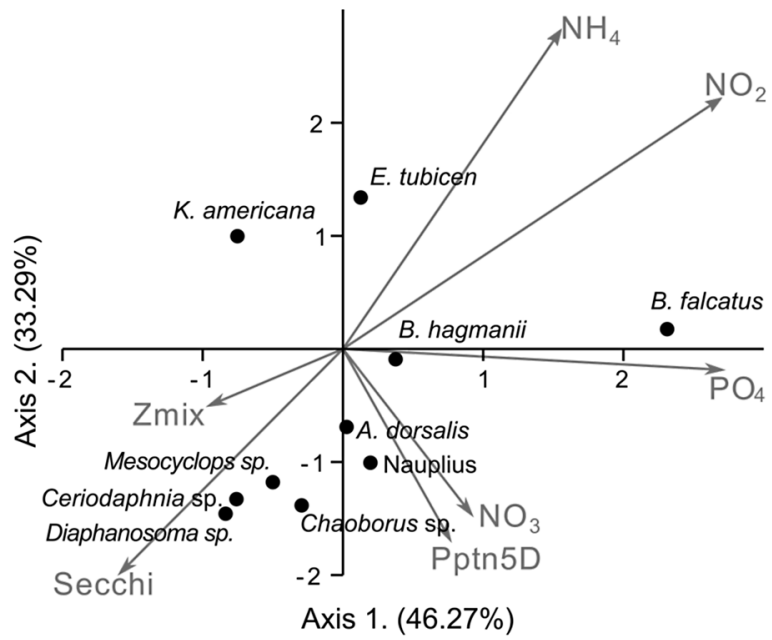

Fig. 10. Result of the CCA of the relationship among environmental parameters and the most abundant species of zooplankton at Lake Río Cuarto 2013-2017.

There are three main groups. The rotifers Filinia sp., Brachionus falcatus and Eubosmina tubicen present greater abundance in some dates of 2013 and 2014. Keratella americana separates from the rest but was also more abundant in some dates of 2013 and 2014. All the other species have greater density in the samplings of the years 2015 and 2016 (Fig. 9).

The Canonical Correspondence Analysis (CCA) showed that certain relationships between the zooplankton and the physical and chemical variables described above are 
evident. It is observed that the abundance of Brachionus falcatus increases positively with the abundance of $\mathrm{PO}_{4}$, Ceriodaphnia sp. and Mesocyclops sp. with $\mathrm{NO}_{3}$ and Keratella americana with $\mathrm{NH}_{4}$. The increase in depth in the Secchi disk and in the depth of the thermocline are positively related to an increase in the genera Diaphanosoma sp., Chauborus sp., Ceriodaphnia sp., but negatively with the rotifers and E. tubicen (Fig. 10).

\section{Relationships between phytoplankton} and zooplankton: The results of the CCA revealed that there are some correspondences between some groups of zooplankton and phytoplankton (Fig. 11). Keratella americana tended to occur when there was a peak of Kirchneriella obesa, and the Cyanobacteria were in low abundance. Brachionus falcatus was more abundant when species of microalgae such as Synechococcus spp., and Aphanocapsa sp., were more abundant, but also Coenochloris fottii, Coenocystis cylindrica, Peridinium volzii and Chlamydomonas sp. were abundant. Eubosmina tubicen was also associated with the abundance of Synechococcus sp. and Aphanocapsa sp. All other species of zooplankton showed higher abundances when the Cyanobacteria were in low abundance, and species like Oocystis lacustris, Oocystis marsonii, Discostella stelligera, Chlorella sp. were abundant. It is interesting to note that predaceous zooplankton such as Chaoborus larvae and Mesocyclops sp. had a positive relationship with the abundance of the larger herbivores in the lake, like Daphnia, Ceriodaphnia, Diaphanosoma, and Arctodiaptomus dorsalis, but a negative relationship with Brachionus falcatus and Keratella americana.

\section{DISCUSSION}

Phytoplankton: Its seasonal variation in some tropical lakes has been associated with changes in the vertical stratification of the lake (Lewis, 1978a; Camacho \& CharpentierEsquivel, 1989; De Leon \& Chalar, 2003; Lopez, Bicudo, \& Ferragut, 2005; HernándezMorales, et al., 2011). This phenomenon is related to the effects that shape and constitution of the algae have on its responses to turbulence and their adaptations to remain in suspension (cf. Lewis, 1978a; Reynolds, 2006). For example, in La Alberca de Tacámbaro, a crater lake in Michoacán Mexico, Hernández-Morales et al. (2011) observed that diatoms were favored during deep mixing events; Chlorophytes were benefited during the establishment of stratification, Cyanobacteria and Dinophyta later during the stratification period (Hernández-Morales et al., 2011). Tropical lakes tend to show a more dynamic alternation of stratification and mixing, since temperature gradients across the

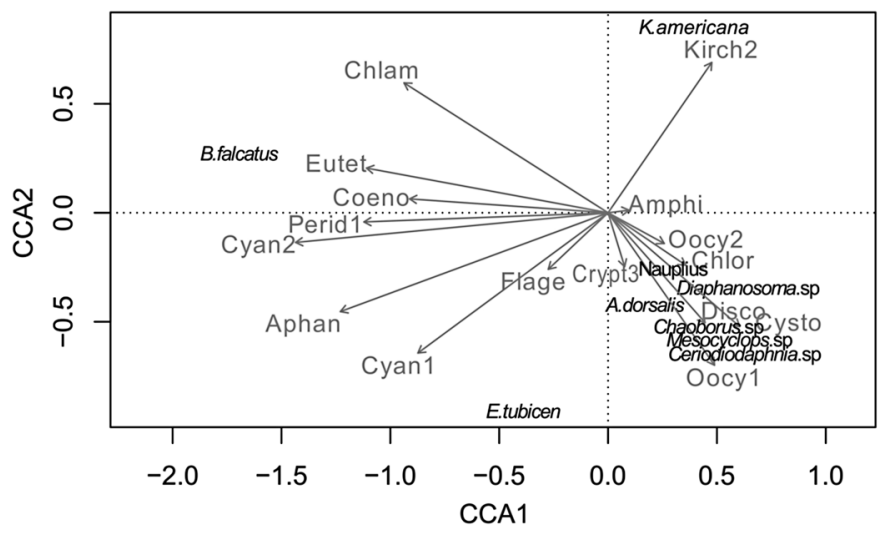

Fig. 11. Result of the CCA of the relationship among the most abundant species of phytoplankton and of zooplankton at Lake Río Cuarto 2013-2017. 
water column are small (Lewis, 1996; RoldánPérez \& Ramírez-Restrepo, 2008). Under such conditions, Lewis and Riehl (1982) proposed that the onset of phytoplankton succession in tropical lakes occurred when the stratification was reestablished, and that the events should follow a general pattern: diatoms, chlorophytes, blue-green algae, dinoflagellates. However, as precipitation and wind are the main seasonal drivers of change in the tropics (Lewis, 1996), and these affect the stratification of the lakes, even at short times scales (Talling \& Lemoalle, 1998), other authors have found that there are shifts in the species composition according to shifts in precipitation (Figueredo \& Giani, 2001; González, Ortaz, Peñaherrera, \& Matos, 2004). In other Costa Rican lakes, where phytoplankton composition has been evaluated weekly for at least one year (Arenal, Barva, Fraijanes, Bonilla), the situation has shown that this sequence not always occurs, and that changes are mainly in the relative contribution of dominant species, rather than a complete change in species composition (Umaña \& Collado, 1990; Umaña-Villalobos, 2010, 2014, 2016). Lopez, Bicudo, and Ferragut (2005) also found a shift in relative contribution of a few dominant species in a shallow subtropical reservoir in Brazil, and González et al. (2004) also reported a similar pattern of small changes in the relative contribution of a few dominant species in El Salto Reservoir, Venezuela.

In the case of Lake Río Cuarto, its phytoplankton has been reported previously as composed of green algae, mainly the filamentous Mougeotia genuflexa, diatoms such as the long and slender Synedra acus, and Nitschia sp., Peridnium inconspicuum, and Anabaena sp. (Umaña-Villalobos, 1985; Camacho \& Charpentier-Esquivel, 1989). Later, in 1991 the lake showed a different phytoplankton composition, with dominance by Cyanophyta, particularly Merismopedia and Dactylococcopsis sp. (Haberyan et al., 1995). However, in this study, species composition has changed again, and it was dominated by Cyanobacteria again, but mainly picocyanobacterial of the genus Synechoccocus and Aphanocapsa, and later with the dominance of small coccoid green algae. These changes reflect a change in the conditions of the lake, which was stratified at more shallow depth than in previous years but showed a deepening of the thermocline and chemocline during the course of the study period (Umaña-Villalobos \& Farah-Pérez, 2018). The changes were not cyclical, but showed a monotonic tendency of decline, mainly due to the decline of Synechoccocus sp. by 2016, which seems to be related to a more deepmixing of the lake that took place at the beginning of that year, which reached more than 20 $\mathrm{m}$ by then (Umaña-Villalobos \& Farah-Pérez, 2018). At the same time some green coccoid algae such as Oocystis lacustris, Discostella stelligera and Amphidinium sp. increased with time. Concomitant with these changes, there was also a shift in the nutrient concentrations in the lakes, with a tendency to decrease with time (Umaña-Villalobos \& Farah-Pérez, 2018). What these data reveal is that year to year variation can be more important in some tropical lakes, even in lakes with very low seasonality and great limnological stability such a Lake Rio Cuarto. Melack (1979) proposed that there are three patterns of fluctuation in phytoplankton of tropical lakes, a seasonal one according the precipitation, a muted variation in lakes where diel variation is greater than seasonal one, and a third one with abrupt changes between persistent algal assemblages. Figueredo and Giani (2001) related temporal changes in phytoplankton community of a tropical reservoir to fluctuations in the local weather (Figueredo \& Giani, 2001). González et al. (2004) found that in their case, an increase in water level at the reservoir during the rainy season, produced a decline in phytoplankton abundance and productivity, as a result of the dilution of the nutrient concentration. A similar pattern was observed in Lake Fraijanes (Umaña-Villalobos, Avilés-Vargas, \& Esquivel-Garrote, 2018).

In our case, data from the nearest stations from the IMN (Station 69079 San Gerardo de Sarapiquí) show that in the region seasonality of precipitation is not clearly distinct, and there is variation between years, as years 
2014-2015 were wetter than the rest. Also, average daily temperature showed a small tendency to increase even in this brief period of time (2013-2017). These changes in weather parallel a shift in the ENSO conditions that occurred during the study period, when an El Niño event took place. So, even small changes in local weather can trigger changes in phytoplankton composition. However, in the case of Río Cuarto, it seems to conform to Melack's (1979) third pattern of variation. Whether these changes in phytoplankton composition are also related to global climate change is not clear, since the lake has roughly maintained its limnological conditions in the past 35 years (Umaña-Villalobos \& Farah-Pérez, 2018).

Zooplankton: In general, there is a change in zooplankton abundance, during the sampling period, with a decrease starting in 2015. This is common because zooplankton organisms are very sensitive to environmental changes, so, abundance, species composition and community structure change drastically according to mixing, rainfall, drought, physical-chemical parameters and trophic state parameters (PintoCoelho et al., 2005; López-López \& SernaHernández, 1999). In this case, as was noted in the results, the changes observed in Lake Río Cuarto may be related to the changes in the trophic levels of the lake, according to the analysis of canonical correspondence. Numerous studies show that nutrients directly influence the composition and abundance of zooplankton communities. For example, the greatest abundance of plankton in all latitudes has been reported in eutrophic ecosystems (Geller \& Müller, 1981; Sládeček, 1983; Bays \& Crisman, 1983; Mäemets, 1983; Manickam, Bhavan, \& Santhanam, 2017; Horppila et al., 2019).

One of the main changes in Lake Río Cuarto zooplankton was the decrease of the two most abundant rotifer species, between the samplings made in 2013 and 2015. Changes in the rotifer community are commonly used as an indicator of water quality; this is so because rotifer sensitivity to the environmental conditions and characteristics like: short life cycles, high population growth rate, great geographic distribution and sensitivity to trophic state, make them good environmental indicators. It is common that the rise in the concentration of nutrients produces an increase in the community of tolerant rotifers (Horppila et al., 2019). The dominant species in lake Río Cuarto, $\mathrm{Bra}$ chionus falcatus and Keratella americana are generally dominant in eutrophic systems; both species are tolerant to pollution and indicate high concentration of organic matter and eutrophication (Manickam et al., 2017; Mäemets, 1983; Sládeček, 1983).

On the other hand, the success of the rotifers is also due to the fact that most of them are suspensivorous and feed on unicellular algae, bacteria and detritus suspended in water, which they centrifuge with the help of their crown. This is an advantage for this group since the nanoseston is the most common source of food in the water column, mainly in eutrophic systems (Gliwicz, 2004).

Eubosmina tubicen was the most abundant Cladocera in Lake Río Cuarto and follows the same pattern of change observed for the rotifers, since its population decreases from the samplings made in 2015 forward. Bosminidae family is usually associated with high concentrations of nutrients (Bays \& Crisman, 1983; García Chicote, 2015; Havens, Beaver, Manis, \& East, 2015), where Cyanobacteria are very abundant (Carpenter, Kitchell, \& Hodgson, 1985; Carpenter \& Kitchell, 1996). This family has advantages over other cladocerans because it presents flexible eating habits, thanks to their thoracic appendages, which allow them to catch particles of different sizes. Besides, it can feed on unicellular bacteria and algae (Bleiwas \& Stokes, 1985). On the other hand, it has the capacity to use less nutritive food and sometimes even to feed on toxic phytoplankton, so this may explain the positive relationship with Cyanobacteria in Río Cuarto (Beaver, Renicker, Tausz, \& Vitanye, 2018). From the above, it can be assumed that the change in the abundance of the rotifers and the small cladocerans is due to a bottom-up control, however it is necessary to take into account also the 
top-down control, since the communities of small cladocerans and rotifers are predated by some copepods of the subfamily Cyclopoida and larvae of Chaoborus sp. (Wen, Xue, Zhang, Xiang, \& Xi, 2019). Both present in the Río Cuarto Lake.

In canonical correspondence analysis it is also evident that other groups of organisms have an inverse relationship with the rotifers, these organisms are Arctodiaptomus dorsalis, Chaoborus sp., Ceriodaphnia sp., Diaphanosoma sp. and in less abundance Mesocyclops sp. Of these organisms Arctodiaptomus dorsalis, Ceriodaphnia sp. and Diaphanosoma sp. are not considered predators, they are herbivorous filter feeders, and therefore the effect in these organisms is related to changes in phytoplankton, generated by changes in nutrients (Tordesillas et al., 2017).

Changes in zooplankton community in Lake Río Cuarto are mainly associated with specific lake conditions. It can be said that to analyze zooplankton variation in tropical lakes, it is necessary to have data from several years of sampling, since changes in the conditions of each lake are generally subtle and occur slowly (Twombly, 1983). On the other hand, the climate tends to be very stable throughout the year, so it does not affect zooplankton communities drastically. It is also always important to analyze biotic and abiotic factors; in future studies it is also recommended to include fish predation and interspecific competition.

Phytoplankton - zooplankton relationships: It is a general assumption that phytoplankton serves as the bases of the food chain in lakes (Wetzel, 2001; Roldán-Pérez, \& Ramírez-Restrepo, 2008), and McCawley and Kalff (1981) developed empirical equations to relate zooplankton biomass to phytoplankton biomass. However, not all zooplankton species can be classified as herbivores (Gliwicz, 2004), and not all suspended particles in lake water are microalgae (Wetzel, 2001; Lewis, 2009). Umaña et al. (2018) did not find a close relationship between phytoplankton and zooplankton in Fraijanes Lake, Costa Rica. Gavlas
(2012) examined the diet of two species of zooplankton in Arenal Reservoir and concluded that both were feeding mainly on particulate organic detritus rather than phytoplankton in the lake water she used for her feeding experiments. A similar conclusion was given by Pace, McManus, and Findlay (1990) who found that zooplankton can feed both on microalgae and bacteria. However, in Lake Río Cuarto, some relationship between given species of phytoplankton and zooplankton was observed, as Eubosmina tubicen showed a decrease that paralleled the plummeting in the abundance of picocyanobacterial such as Synechococcus spp. Nevertheless, these changes were not cyclical on an annual basis. In the tropics, the temporal variation in the abundance of either phytoplankton and zooplankton seem to be less pronounced and predictable than in temperate lakes, since selective pressures on composition due to trophic relationships are at work all year round, and that the effect of the presence or absence of a consumer is masked by the constancy of the environmental conditions. On the other hand, it is generally accepted that predator-prey relationships are cyclical according to theoretical reasoning (Gotelli, 2001), so the lack of clear correlations might also be an artifact from low frequency of sampling, given that planktic species have fast growing rates, especially at the high temperatures in this low land tropical lake.

Ethical statement: authors declare that they all agree with this publication and made significant contributions; that there is no conflict of interest of any kind; and that we followed all pertinent ethical and legal procedures and requirements. All financial sources are fully and clearly stated in the acknowledgements section. A signed document has been filed in the journal archives.

\section{ACKNOWLEDGMENTS}

We want to express our great appreciation to the help of many people that came along and helped with the field trips, including 
Aldo Farah-Pérez, Beatriz Naranjo, Juan Carlos Azofeifa, Carlos Garita, Paola Campos, Jareth Román, Josefina Brais, Juan Diego León, Carlos Calderón. We want to thank also to Ing. Gonzalo Delgado, who granted the entrance to the lake at the early beginnings of the study. This study was possible thanks to a grant from the Vicerrectory of Research to the Center of Research on Marine Sciences and Limnology (CIMAR), of the University of Costa Rica, project No. 808-B3-133.

\section{RESUMEN}

Variación del plancton en el lago Río Cuarto, Costa Rica (2013 al 2017). En los lagos tropicales, los cambios estacionales en la dinámica del plancton son mínimos e irregulares, ya que las condiciones climáticas son bastante estables durante todo el año, en la mayoría de los casos solamente estudios a largo plazo permiten observar patrones en la dinámica del plancton. El lago de Río Cuarto es un lago meromícto tipo maar localizado en las llanuras del norte de Costa Rica, en el pasado se han realizado estudios limnológicos no mayores a un año de muestreo, en este trabajo presentamos datos de la composición del fitoplancton y del zooplancton a lo largo de cuatro años, del 2013 al 2017, con el fin de analizar cambios en la comunidad del plancton en un periodo de tiempo mayor, asociados a variables ambientales. Para el fitoplancton se tomaron muestras subsuperficiales y se fijaron con lugol, y para el zooplancton se hicieron arrastres verticales de $20 \mathrm{~m}$ con una red con $64 \mu \mathrm{m}$ de poro, que se preservaron con formalina y luego se pasaron a alcohol de $95 \%$. El fitoplancton incluyó 54 taxa, la mayoría fue Chlorophyta, seguidos por Cyanobacteria y Bacillariophyta. Las taxa más comunes fueron: Synechococcus spp., Aphanocapsa sp. Coenochloris fotii, Chlorella sp. y Discostella stelligera. La abundancia total del fitoplancton disminuyó de 2013 a 2017, principalmente debido a una disminución en las Cyanobacteria. El zooplancton estuvo compuesto por 14 taxa: 5 cladóceros, 4 copépodos, 1 díptero y 4 rotíferos. Los más abundantes fueron: Keratella americana, Brachionus falcatus, Eubosmina tubicen y Arctodiaptomus dorsalis. Se observó un cambio en la diversidad y abundancia del zooplancton, al principio (2013-2014) K. americana y E. tubicen se alternaron en dominancia, y luego (2015-2016) A. dorsalis, Diaphanosoma sp. y Ceriodaphnia sp. fueron dominantes, con un regreso de K. americana en el 2017. Los cambios observados en el periodo de estudio parecen estar relacionados con cambios en la condición del lago, pues la termoclina se hundió y el lago se volvió más trasparente durante el estudio. La abundancia, de rotíferos y del cladócero Eubosmina tubicen, disminuyó asociada a una disminución de Cyanobacterias. Esos cambios no siguieron un ciclo anual, más bien parecen cambios que ocurren a largo plazo, tal y como se ha propuesto en la literatura sobre lagos tropicales.

Palabras clave: fitoplancton, zooplancton, variación temporal, lagos meromícticos, Costa Rica.

\section{REFERENCES}

Arrieiraa, R. L., Schwinda, L. T., Jokob, C. Y., Alvesc, G. M., Velhoa, L. F., \& Lansac-Tôhaa, F. M. (2016). Relationships between environmental conditions and the morphological variability of planktonic testate amoeba in four neotropical floodplains. European Journal of Protistology, 56, 180-190.

Bays, J. S., \& Crisman, T. L. (1983). Zooplankton and trophic state relationships in Florida lakes. Canadian Journal of Fisheries and Aquatic Sciences, 40(10), 1813-1819. DOI: 10.1139/f83-210

Beaver, J. R., Renicker, T. R., Tausz, C. E., \& Vitanye, B. T. (2018). Distribution of six taxa in the family Bosminidae Baird (Crustacea: Branchiopoda: Anomopoda) in the plankton of lakes and reservoirs within the continental United States, including expanded range of the invasive cladoceran Bosmina (Eubosmina) coregoni Baird. Zootaxa, 4407(4), 506-520.

Bleiwas, A. H., \& Stokes, P. M. (1985). Collection of large and small food particles by Bosmina. Limnology and Oceanography, 30(5), 1090-1092.

Camacho, V. L., \& Charpentier-Esquivel, C. (1985). Occurrencia y distribución vertical de las algas planctónicas del Lago de Río Cuarto, Alajuela, Costa Rica (Postgraduate thesis). Universidad de Costa Rica, San José, Costa Rica.

Camacho, V. L., \& Charpentier-Esquivel, C. (1989). Ciclo anual del fitplancton en el Lago de Río Cuarto, Costa Rica. Uniciencia, 6(1), 17-22.

Carpenter, S. R., \& Kitchell, J. F. (Eds.). (1996). The Trophic Cascade in Lakes. Cambridge: University Press.

Carpenter, S., Kitchell, J., \& Hodgson, J. (1985). Cascading trophic interactions and lake productivity. BioScience, 35(10), 634-639.

Charpentier-Esquivel, C., Tabash-Blanco, F. A., Fallas, I. A, Zumbado, J. C., Camacho-Vargas, L., \& RamírezRamírez, E. (1988). Variación estacional en el Lago de Río Cuarto, Provincia de Alajuela, Costa Rica. I. Limnología físico-química. Uniciencia, 5(1/2), $77-85$.

Claps, M. C., Gabellone, N. A., \& Benítez, H. H. (2011). Seasonal Changes in the Vertical Distribution of Rotifers in a Eutrophic Shallow Lake with Contrasting States of Clear and Turbid Water. Journal of Environmental Protection, 50(4), 454-465. 
De Leon, L., \& Chalar, G. (2003). Abundancia y diversidad del fitoplancton en el Embalse de Salto Grande (Argentina - Uruguay). Ciclo estacional y distribuciónespacial. Limentica, 22(1-2), 103-113.

De Senerpont Domis, L., Elser, J. J., Gsell, A., Huszar, V. L. M., Ibelings, B. W., Jeppesen, E., ... Winder, M. (2012). Plankton dynamics under different climatic conditions in space and time. Freshwater Biology, $58(3), 463-482$.

Fernando, C. H. (Ed.). (2002). A guide to tropical freshwater zooplankton. Identification, ecology and impact on fisheries. Leiden, Netherlands: Backhuys Publishers.

Figueredo, C. C., \& Giani, A. (2001). Seasonal variation in the diversity and species richness of phytoplankton in a tropical eutrophic reservoir. Hydrobiologia, 445(13), $165-174$.

García Chicote, J. (2015). El zooplancton como indicador de la calidad del agua en embalses: un estudio en el ámbito de actuación de la Confederación Hidrográfica del Júcar (Doctoral thesis). Universitat de València, Valencia, España.

Gavlas, A. M. (2012). Cambios estacionales y relaciones alimentarias de la comunidad planctónica del Embalse Arenal, Costa Rica (Master's thesis). Universidad de Costa Rica, San José, Costa Rica.

Geller, W., \& Müller, H. (1981). The filtration apparatus of Cladocera: filter mesh-sizes and their implications on food selectivity. Oecologia, 49(3), 316-321.

Gliwicz, Z. M. (2004). Zooplankton. In P. E. O’Sullivan, \& C. S. Reynolds (Eds.), The Lakes Handbook: Limnology and Limnetic Ecology (Vol. 1). Oxford, U. K.: Blackwell Publishing.

Gocke, K., Bussing, W., \& Cortés, J. (1987). Morphometric and basic limnological properties of the Laguna de Río Cuarto, Costa Rica. Revista de Biología Tropical, $35(2), 277-285$.

Gocke, K., Bussing, W., \& Cortés, (1990). The annual cycle of primary productivity in Laguna Río Cuarto, a volcanic (maar) in Costa Rica. Revista de Biología Tropical, 38(2B), 387-394.

González, E. J, Ortaz, M., Peñaherrera, C., \& Matos, M. L. (2004). Fitoplancton de un embalse tropical hipereutrófico (Pao-Cachinche, Venezuela): abundancia, biomasa y producción primaria. Interciencia, 29(10), 548-555.

Gotelli, N. J. (2001). A Primer of Ecology (No. 504 GOT). Sunderland, MA: Sinauer Associates.

Haberyan, K., Umaña, G., Collado, C., \& Horn, S. (1995). Observations on the plankton of some Costa Rican lakes. Hydrobiologia, 312(2), 75-85.
Hammer, Ø., Harper, D. A. T., \& Ryan, P. D. (2001). PAST: Paleontological statistics software package for education and data analysis. Palaeontologia Electronica, 4(1), 9. Retrieved from http://palaeoelectronica.org/2001_1/past/issue1_01.htm

Havens, K. E., Beaver, J. R., Manis, E. E., \& East, T. L. (2015). Inter-lake comparisons indicate that fish predation, rather than high temperature, is the major driver of summer decline in Daphnia and other changes among cladoceran zooplankton in subtropical Florida lakes. Hydrobiologia, 750(1), 57-67. DOI: 10.1007/ s10750-015-2177-5.

Hernández-Morales, R., Ortega, M. R., Sánchez, J. D., Alvarado, R., \& Aguilera, M. S. (2011). Distribución estacional del fitoplancton en un lago monomíctico en Michoacán, México. Biológicas, 13(2), 21-28

Horppila, J., Härkönen, L., Hellén, N., Estlander, S., Pekcan-Hekim, Z., \& Ojala, A. (2019). Rotifer communities under variable predation-turbulence combinations. Hydrobiologia, 828(1), 339-351.

Huber-Pestalozzi, G. (1955). Das Phytoplankton des Süsswassers, Systematik und Biologie. 4. Teil: Euglenophyceen. Sttutgart, Deutschland: E. Schweizerbart'sche Verlagsuchhandlung.

Huber-Pestalozzi, G. (1961). Das Phytoplankton des Süsswassers, Systematik und Biologie. 5. Teil: Chlorophyceae (Grünalgen) Ordnung: Volvocales. Sttutgart, Deutschland: E. Schweizerbart'sche Verlagsuchhandlung.

Huber-Pestalozzi, G. (1968a). Das Phytoplankton des Susswassers. 3 Teil. Cryptophyceae, Chloromonadophyceae, Dinophyceae. Mit einem Beitrag von B. Fott. Sttutgart, Deutschland: E. Schweizerbart'sche Verlagshandlung.

Huber-Pestalozzi, G. (1968b). Das Phytoplankton des Süsswassers, Systematik und Biologie. 3. Teil: Cryptophyceae, Chloromonadophyceae, Dinophyceae (2 $2^{\text {nd }}$ Ed.). Sttutgart, Deutschland: E. Schweizerbart'sche Verlagsuchhandlung.

Imevbore, A. M. (1967). Hydrology and plankton of Eleiyele Reservoir, Ibadan, Nigeria. Hydrobiologia, 30(1), 154-176.

John, D. M., Whitton, B. A., \& Brook, A. J. (2005). The freshwater algalflora of the British Isles, an identification guide to the freshwater and terrestrial algae. Cambridge, U.K.: Cambridge University Press.

Komárek, J. (1983). Contribution to the Chlorococcal algae of Cuba. Nova Hedwigia, 37, 65-180.

Kotov, A. A., \& Stifter, P. (2006). Ilyocryptidae of the World. Guides to the Identification of the Microinvertebrates of the Continental Waters of the World (22, 1-172). 
Krammer, K., \& Lange-Bertalot, H. (1991) Süßwasserflora von Mitteleuropa. Bacillariophyceae 3. Teil: Centrales, Fragilariaceae, Eunotiaceae. Sttutgart, Deutschland: Gustav-Fischer Verlag.

Lewis, W. M. (1996). Tropical lakes: how latitude makes a difference. In F. Schiemer \& K. T. Boland (Eds.), Perspectives in Tropical Limnology (pp.43-64). Amsterdam, Holland: SPB Academic Publishing.

Lewis, W. M. (1978a). Dynamics and Succession of the Phytoplankton in a Tropical Lake: Lake Lanao. Journal of Ecology, 66, 849-880.

Lewis, W. M. (1978b). Comparison of Temporal and Spatial Variation in the Zooplankton of a Lake by Means of Variance Components. Ecology, 59(4), 666-671.

Lewis, W. M. (2009). Lake ecosystems: structure, function and change. In G. E. Likens (Ed.), Lake Ecosystem Ecology: A Global Perspective. Encyclopedia of Inland Waters (pp. 1-10). Massachusetts, Unite States: Academic Press.

Lewis Jr, W. M., \& Riehl, W. (1982). Phytoplankton composition and morphology in Lake Valencia. Venezuela. Internationale Revue des gesamten. Hydrobiologie, 67, 297-322.

Lopez, M. R. M., Bicudo, C. E. de M., \& Ferragut, M. C. (2005). Short term spatial and temporal variation of phytoplankton in a shallow tropical oligotrophic reservoir, southern Brazil. Hydrobiologia, 542, 235247. DOI: $10-1007 / \mathrm{s} 10750-8332-\mathrm{z}$

López-López, E., \& Serna-Hernández, J. A. (1999). Variación estacional del zooplancton del embalse Ignacio Allende, Guanajuato, México y su relación con el fitoplancton y factores ambientales. Revista de Biología Tropical, 47(4), 643-657.

Mäemets, A. (1983). Rotifers as indicators of lake types in Estonia. Hydrobiologia, 104(1), 357-361.

Manickam, N., Bhavan, P. S., \& Santhanam, P. (2017). Seasonal Variations in Species Composition and Community Structure of Zooplankton in A Two Perennial Lakes of Coimbatore, Tamil Nadu, Southern India. Journal of Aquatic Research and Marine Sciences, 2017, 1-12.

McCawley, E., \& Kalff, J. (1981). Empirical relationships between phytoplankton and zooplankton biomass in lakes. Canadian Journal of Fisheries and Aquatic Sciences, 38(4), 458-463.

Melack, J. M. (1979). Temporal variability of phytoplankton in tropical lakes. Oecologia, 44(1), 1-7.

Offem, B. O., Ezekiel, O. A., Ikpi, G. U., Ochang, S. N., \& Ada, F. A. (2011). Influence of Seasons on Water Quality, Abundance of Fish and Plankton Species of Ikwori Lake, South-Eastern Nigeria. Fisheries and Aquaculture Journal, 2011, FAJ-13.
Pace, M. L., McManus, G. B., \& Findlay, S. E. G. (1990). Planktonic community structure determines the fate of bacterial production in a temperate lake. Limnology and Oceanography, 35(4), 795-808.

Parsons, T. R., Maita, Y., \& Lalli, C. M. (1984). A manual of chemical and biological methods for seawater analysis. Oxford, England: Pergamon Press.

Pérez, L., Lorenschat, J., Massaferro, J., Pailles, C., Sylvestre, F., Hollwedel, W., ..., Lozano, M. S. (2013). Bioindicators of climate and trophic state in lowland and highland aquatic ecosystems of the Northern Neotropicos. Revista de Biología Tropical, 61(2), 603-644.

Pinto-Coelho, R., Pinel-Alloul, B., Méthot, G., \& Havens, K. E. (2005). Crustacean zooplankton in lakes and reservoirs of temperate and tropical regions: variation with trophic status. Canadian Journal of Fisheries and Aquatic Sciences, 62(2), 348-361. DOI: 10.1139/ f04-178

R Core Team (2013). R: A language and environment for statistical computing. R Foundation for Statistical Computing, Vienna, Austria. Retrieved from http:// www.R-project.org

Ramírez-Ramírez, E., Tabash-Blanco, F., \& CharpentierEsquivel, C. (1990).Variación estacional en el lago de Río Cuarto, provincia de Alajuela, Costa Rica. Unicencia, 7(1), 19-25.

Reynolds, C. S. (1984a). The Ecology of Freshwater Phytoplankton. Cambridge: Cambridge University Press.

Reynolds, C. S. (1984b). Phytoplankton periodicity: the interactions of form, function and environmental variability. Freshwater Biology, 14(2), 111-142.

Reynolds, C. S. (2006). Ecology of Phytoplankton. UK: Cambridge University Press.

Rodriguez, L. C., Simoes, N. R., Bovo-Scoparin, V. M., Jati, S., Santana, N. F., Roberto, M. C., \& Train, S. (2015). Phytoplankton alpha diversity as an indicator of environmental changes in a neotropical floodplain. Ecological Indicators, 48, 334-341. DOI: 10.1016/j. ecolind.2014.08.009

Roldán-Pérez, G. \& Ramírez-Restrepo, J. J. (2008). Fundamentos de Limnología neotropical. Colombia: Universidad de Antioquía.

Shiel, R. J. (1995). A guide to the identification of Rotifers, Cladocerans and Copepods from Australian inland waters. Albury, Australia: The Murray-Darling Freshwater Research Center.

Simões, N. R., Lansac-Tôha, F. A., Velho, L. F. M., \& Bonecker, C. C. (2012). Intra and inter-annual structure of zooplankton communities in floodplain lakes: a long-term ecological research study. Revista de Biología Tropical, 60(4), 1819-1836. 
Sládeček, V. (1983). Rotifers as indicators of water quality. Hydrobiologia, 100(1), 169-201.

Sommer, U., Adrian, U., De Senerpont Domis, L., Elser, J. J., Gaedke, U., Ibelings, B., ... Jeppesen, E. (2012). Beyond the Plankton Ecology Group (PEG) model: mechanisms driving plankton succession. Annual Review of Ecology, Evolution and Systematics, 43, 429-48.

Sommer, U., Gliwicz, Z. M., Lampert, W., \& Duncan, A. (1986). The PEG-model of seasonal succession of planktonic events in freshwaters. Archives für. Hydrobiologie, 106(4), 433-471.

Suthers, I. M. (2009). Plankton: A Guide to Their Ecology and Monitoring for Water Quality. Collingwood, Australia: Csiro Publishing.

Talling, J. F., \& Lemoalle, J. (1998). Ecological Dynamics of Tropical Inland Waters. Cambridge: Cambridge University Press.

Tordesillas, D. T., Paredes, P. M., Villaruel, K. P., Queneri, C. A., Rico, J. L., Ban, S., \& Papa, R. D. (2017). Effects of food concentration on the reproductive capacity of the invasive freshwater calanoid copepod Arctodiaptomus dorsalis (Marsh, 1907) in the Philippines. Journal of Crustacean Biology, 38(1), 101-106.

Twombly, S. (1983). Seasonal and short term fluctuations in zooplankton abundance in tropical Lake Malawi. Limnology and Oceanography, 28(6), 1214-1224.

Twombly, S., \& Lewis Jr, W. M. (1987). Zooplankton abundance and species composition in Laguna la Orsinera, a Venezuelan floodplain lake. Archives für. Hydrobiologie. Supplementband. Monographische Beiträge, 79(1), 87-127.

Umaña, V. G. \& Collado, C. (1990). Asociación planctónica en el Embalse Arenal, Costa Rica. Revista de Biología Tropical, 38(2A), 311-321.

Umaña-Villalobos, G. (1985). Phytoplankton species diversity of 27 lakes and ponds in Costa Rica (Central America) (Master's thesis). Brock University, Ontario.

Umaña-Villalobos, G. (2010). Temporal variation of phytoplankton in a small tropical crater lake, Costa. Revista de Biología Tropical, 58(4), 1405-1419.

Umaña-Villalobos, G. (2014). Phytoplankton variability in Lake Fraijanes, Costa Rica, in response to local weather variation. Revista de Biología Tropical, 62(2), 483-494.

Umaña-Villalobos, G. (2016). One year weekly dynamics of limnological conditions and phytoplankton in Lake Bonilla, Costa Rica. Revista de Biología Tropical, 64(4), 1771-1781.

Umaña-Villalobos, G., Avilés-Vargas, L., \& EsquivelGarrote, O. (2018). Zooplankton variation in Fraijanes Lake (Costa Rica) during the course of one year. Revista de Biología Tropical, 66(S1), S123-S131.

Umaña-Villalobos, G., \& Farah-Pérez, A. (2018). Revisiting the limnology of Lake Río Cuarto, thirty years later. Revista de Biología Tropical, 66(1-1), S42-S52.

Wehr, J. D., \& Sheath, R. G. (Eds.). (2003). Freshwater algae of North America, ecology and classification. Amsterdam: Academic Press.

Wen, X. L., Xue, Y. H., Zhang, G., Xiang, X. L., \& Xi, Y. L. (2019). Ecological mechanisms regulating the dynamics of the field rotifer population in a subtropical lake: evidence from the density, reproduction, and morphology of a case rotifer, Brachionus angularis. Journal of Freshwater Ecology, 34(1), 49-63.

West, W., \& West, G. S. (1904). A monograph of the Brititsh Desmidiaceae (Vol. I). London: Johnson Reprint Corporation.

West, W., \& West, G. S. (1905). A monograph of the Brititsh Desmidiaceae (Vol. II). London: Johnson Reprint Corporation.

West, W., \& West, G. S. (1908). A monograph of the Brititsh Desmidiaceae (Vol. III). London: Johnson Reprint Corporation.

West, W., \& West, G. S. (1912). A monograph of the Brititsh Desmidiaceae (Vol. IV). London: Johnson Reprint Corporation.

West, W., \& West, G. S. (1923). A monograph of the Brititsh Desmidiaceae (Volume V). London: Johnson Reprint Corporation.

Wetzel, R. G. (2001). Limnology, Lake and River Ecosystems. San Diego California: Academic Press.

Zehrer, R. F., Burns, C. W., \& Flöder, S. (2014). Sediment resuspension, salinity and temperature affect the plankton community of a shallow coastal lake. Marine and Freshwater Research, 66(4), 317-328. 